\title{
Effect of Head Teachers' Managerial Styles on the Teachers' Professional and Organizational Commitment
}

\author{
Muhammad Abdullah Khan* \\ Shafqat Hussain ${ }^{* *}$
}

\begin{abstract}
This study was aimed to investigate the effect of three managerial styles i.e. autocratic, democratic, and laissez-faire of head teachers on the professional and organization commitment of teachers at elementary level. This research is descriptive and correlation in nature. A survey instrument was self-developed and validated through expert opinions and pilot study. The stratified cluster random sampling technique was used to select 540 teachers (40\%) including 274 male and 266 female from the population. The findings of the study show that most practiced managerial style was democratic and least practice was laissez-faire. The organizational and professional commitment levels of the teachers were significantly positive correlated with democratic and negative correlated with autocratic managerial style. It is recommended that head teachers may adopt democratic managerial style to enhance the professional and organizational commitment of teachers. The Punjab Education Department may arrange the training through Directorate of Staff Development for head teachers to practice democratic managerial style to increase the organizational and professional commitment of teachers. Head teachers may develop passion of duty and commitment in teachers by making educational and organizational plan with the collaboration of teachers and assigning duties according to their abilities, interests and willingness. The effect of other variables on teachers' commitment like national educational policies, cooperation of community and parents, work environment, academic qualification, professional qualification and experience of teachers may be examine in further studies.
\end{abstract}

Keywords: Democratic, Autocratic, Laissez-faire, Professional Commitment, Organizational Commitment

* $\quad$ M. Phil Scholar University of Sargodha, Mianwali Campus

** Assistant Professor, University of Sargodha, Mianwali Campus 


\section{Introduction}

The study examines the effect of three managerial styles i.e. autocratic (AMS), democratic (DMS), and laissez-faire managerial style (LMS) of head teachers on professional commitment of teachers (PCOT) and organizational commitment of teachers (OCOT). Key elements of education are schools, head teachers, teachers and students; they all are interlinked with each other. The head Teachers are leaders and managers in schools and have powerful effect on the teachers and teachers have powerful effect on the students. No education system can be improved without the quality of its teachers because teachers perform his duty in classroom particularly and in the school environment in-general.

The purpose of the study was to identify more practice managerial style of head teachers and to find out relationship between managerial styles of head teachers and teachers' professional commitment and organizational commitment. For achieving these objectives two research questions, two null and two non-directional hypotheses were developed. The research questions were: Which one is the most practiced managerial style of head teachers? Which type of head teachers' managerial style promotes teachers' organizational and professional commitment? The null hypotheses were: There is no significant difference between the perception of male and female teachers about their head teachers' practiced managerial style. There is no significant difference between the perceptions of male and female teachers about their organizational and professional commitment. Non-directional hypotheses were: There is significant relationship of head teachers' managerial styles with organizational and professional commitment of teachers. There is significant effect of head teachers' managerial styles on organizational and professional commitment of teachers.

\section{Literature Review}

\section{Leadership and Management}

Bush (2006) denotes that field of educational leadership and management is almost same with many contending perceptions and an expected absence of contract on the particular natural world of the authority. A significant discussion has been elaborated that educational leadership is a diverse field or a branch of the broad study of management. Bush (1999) says that managerialism is a pressure on actions for the disbursement of educational function, ethics and values. 


\section{Management of School}

Thomas (1999) states that management of school means surroundings accurate objectives these objectives engage different stages, set aims, assigning resources, providing results, estimating the impact, and sketch action strategies to achieve them. The functioning part of the administrator is similarly manager. Massie (1992) states that management is to obtain things complete all the way through other peoples. Kraus and Curtis (1986) argued that Head teachers must work by others to attain administrative aims and objectives. Certo (2003) argued that functions of management are behavior that build the management procedure, planning, organizing, influencing and controlling are four basic behaviors of management.

\section{Role of Head Teachers' in Teachers’ Commitment}

Ahmad (2004) state that head teachers is the greater and important individual in school. Part of a school, head teachers is careful as the chief, primary significant individual in the confirming the success of the school and good organization in running the school. Lambertz (2002) denotes that teachers and policymakers equally look for an effective leadership that can create sustainable school enhancement and teacher commitment. leadership style that boosts employees' commitment is necessary for an organization to successfully attaining their objective (Swanepoel, Erasmus, Schenk, \& Van, 2000). School leadership has been converted into significance in education policy schedules globally. It plays a key role in school environment. Active school leadership is important for improving proficiency and neutrality of schooling (Policy, 2008). School leadership is careful to be greatly important in persuading teachers' levels of agreements with new goals and developments (Day, 2000; Fullan, 2002). Elliott and Crosswell (2002) argued that this is due to school principals are assumed to be the transcribers and connectors amongst the schools and the organizational objectives and priorities and definite teacher practice.

\section{Managerial Leadership}

According to Leithwood, Jantzi, and Steinbach (1999) managerial leadership accepts that the focus of leaders must to be on tasks, functions, behaviors. Most approaches to managerial headship also adopt that the behavior of organizational members is rational. This definition is 
extraordinarily close to the definition that is given for 'formal models' in the author's series of books on a related topic, managers and leaders of self-managing schools should be able to develop and imply a cyclical process involving seven managerial functions such as budgeting, evaluation, goal setting, needs- identification, priority-setting, planning and implement(Bush, 1989, 1995, 2003; Caldwell, 1992).

\section{Model of Management and Leadership}

Bush (2003) define the typology of management and Leadership models as; in Management model is cover Formal, Collegial, Political, Subjective, Ambiguity and cultural whereas in Leadership model cover Managerial, Participative, Transformational, Interpersonal, Transformational, Post-modem, Contingency, Moral, Instructional.

\section{Leadership Styles}

Leadership Style means the ways/method through which a leader influences his subordinates/followers. Ribbins (1999)stated that leaders depend on styles which are democratic, autocratic and laissez-fair. A democratic style is characterized by co-operation, co-ordination and by collaboration. Yulk (2005) argued that “Autocratic leadership style allows no participation in laissez-fair and decision which is also known as (free-rein leadership) style that empowers subsidiary to work with freedom. The quality of leadership is a definite style of leader, which may have been played a basic role in making the association between leaders. Effective enactment signals the transformational capacity of leadership and impact, that may have influence on the assistants (Grosso, 2008).

\section{Autocratic Leadership Style}

Autocratic leadership involves a high level of power, attitude that makes most of the important decisions yourself as the leader. Though detailed literature has been issued on participation of leadership however in Autocratic leadership, there is not any agreement on general decision (Yukl, 1994). The "dele-gated", where the decision making comity has responsibility to take final the decision, even if the administrator demands previous agreement about it (Vroom \& Yetton, 1973; Yukl, 1994). More the participation of educators in decision making procedure leads the greater steps of job approval. Such type of hypothesis is established on research of contribution in decision making and on the 
association amongst educator job satisfaction (Imber, Neidt,\& Reyes, 1990; Rice \& Schneider, 1994; Schneider, 1984). In such environment, leaders are as representative administrator which provides the association with their staff. Educators would be more pleased with their job as compared to institutes where leaders possess a rude and imperious behavior (Kottkamp, Mulhern \& Hoy, 1987).

Autocratic leadership style contains the leader for making final decisions, apply full power, give tasks for participants and retain a master-servant correlation with group followers Omolayo (2007) and Musaazi (1988) described three fundamental administrative styles comprise autocratic, democratic and laissez faire.

\section{Democratic Leadership Style}

Schwartz (1983) found a high gentleness among workers in democratic organizations. Lewin, Lippitt, and White (1939) concluded that democratic style is the most effective than any other leadership style. The school where democratic leadership style is adopted, there will be good mutual understanding, co-operation.

\section{Laissez-faire Leadership Style}

The laissez-faire leadership style, where all the rights and authority gave to workers completely. This was first defined by Lewin et al. (1939), This type of leadership gives completely self-determination either to make decisions or to complete an assignment in whatever the method they consider suitable to his subordinates (Robbins, 2010). Hamidifar (2010) remarked that leaders who are working the leadership style are generally doing carelessly and take not any interest on problems that get up in the institute environment. Laissez-faire is denoting to "hands off, let things-ride" a method in its real French style. Leaders of Laissez-faire have been assumed to no involvement in decision making and have no strong interest to support followers and sustaining their requirements (Northouse, 2010).

\section{Teachers' Commitment}

In the light of previous studies there are two types of teacher's commitment, organizational commitment and Personal commitment. Organizational commitment linked with performances and believes connected to the ease of an organization (Mowday, Steers \& Porter, 1979). While personal commitment discusses the views and activities 
concerning the school community, education profession, and learners (Elliott \& Crosswell, 2002).

\section{Professional Commitment}

Nazari and Emami (2012) pointed out that the professional commitment refer the self-control of power of an workers' records along with the goal line and evaluate of their right, having more trust and displaying significant motivation to attach with the profession and fully involvement in the professional activities. Gehlawat (2013) stated that teachers of private institutes are greater attached to their privilege than in public assembly. Gerald (2011) stated that young educators are more involved than older ones and have more experience but Burcak (2013) establish no symbol dissimilitude in commitment by approval to period while Hanlon (1983) disagreed with this previous statement. According to him old educators are further attached as compared to young ones. Seeing kind, certainly must have measured that ladies' independent of reduction is greater than the gents' level of commitment (Chan, Lau, Nie, Lim \& Hogan, 2008). Nevertheless, the discoveries of Borman and Dowling (2008) denoted humble undertaking of women.

Affective professional commitment relate to educators' excitable relationship to, documentation by, and distribution in the education employment and its aims in remark to need of the educator to recognize by and the desire not to omit the profession for deep wish (Bagraim, 2003; Ware \& Kitsantas, 2007). The normative professional commitment discusses with the approach of moral duty of individuals to stay in the job (Allen \& Meyer, 1993; Bagraim, 2003; Ware \& Kitsantas, 2007). According to this, the sense of responsibility of the employee towards their profession (Maheshwari, Bhat \& Dhiman, 2007). Nazari and Emami (2012) argued that continuance commitment based on the reimbursement and expenses that is related to keep on in the profession. Ware and Kitsantas (2007) pointed out that the degree to which persons considers that they must remain in the teaching profession because of lack of alternatives or possible disruptions resulting from leaving their profession. Maheshwari, Bhat, and Dhiman (2007) stated that it is the economic compulsions that make the professionals stay with the profession and its values. 


\section{Organizational Commitment}

Allen and Meyer (1993) stated about organizational commitment, determines three separate kinds of business commitment, the affective, prescriptive, and continue business condemnation. These professional commitments relate to: (a) excitable, (b) passion of duty, and (c) financial object of personae. Man may be committed to the declaration, as one of the overheads inhere emotional summit meeting or union of two or more than two are involved. Walumbwa, Lawler, Avolio, Wang and Shi (2005) found that an employee's willingly involvement and commitment to the organization is called organizational commitment. Worker commitment is explained in a method as the worker's emotional connection to the institute (Marmaya, Hitam, Torsiman \& Balakrishnan, 2011). Administrative commitment has generally been reflected as a person's attachment with the institute and his or her willingness to use energy for institutional welfare (Walumbwa, Lawler, Avolio, Wang, \& Shi, 2005).

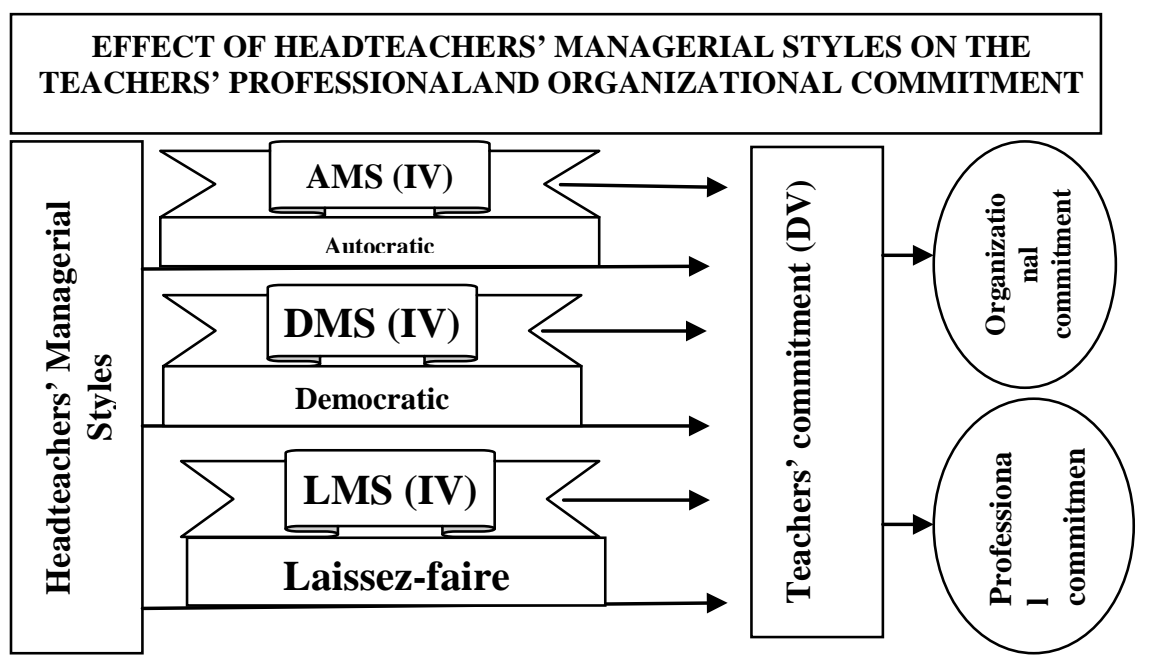

Figure 1. Theoretical framework of the study 


\section{Methodology}

\section{Research Design}

This research is descriptive and correlation in nature. The data was collected personally and with the help of three research associates.

\section{Participants}

The participants of the study were teachers of public sector elementary schools in district Mianwali. Total 40 male and 30 female public sector elementary schools in district Mianwali were selected through stratified cluster random sampling techniques. The sample of 540 including 274 male and 266 female teachers was taken from population.

\section{Instruments}

In order to draw valid conclusions from research, reliable and valid instrument must be used for measuring the variables, so a questionnaire was prepared after going through the relevant literature and keeping in view all the important aspects and variables of the topic of the study. This questionnaire was developed by using five-point likert scale.

\section{Reliability and Validity}

In order to check validity of the questionnaires, it was distributed among five experts. In order to check reliability and validity,50 questionnaires were administer on 35 male and 15 female elementary school teachers in 6 schools. The reliability of the questionnaire was checked by applying Cronbach's Alpha, which was 0.90 that is good to administer at large scale.

\section{Data Analysis}

Data collected through questionnaire, was tabulated and analyzed by applying mean score, Independent sample t-test, Pearson correlation, and regression, using SPSS version.

Table1

Description of Head Teachers' managerial by Mean Scores

\begin{tabular}{llll}
\hline Managerial Styles & $\begin{array}{l}\text { Sum } \\
\text { responses }\end{array}$ & $\begin{array}{l}\text { of } \\
\text { of responses }\end{array}$ & Mean Score \\
\hline Democratic Managerial Style (DMS) & 2109 & 78 & 3.905 \\
Laissez-faire Managerial Style(LMS) & 1688 & 62 & 3.127 \\
Autocratic Managerial Style(AMS) & 1246 & 46 & 2.309 \\
\hline${ }^{*}=540 * * *$ (Criterion Men $=3$ ) & &
\end{tabular}

${ }^{*} \mathrm{~N}=540 * * *($ Criterion Mean $=3$ ) 
Table 1 depicts the most dominant managerial style of Head Teachers by mean scores. Mean Scores 3.90 of democratic managerial style shows that this Style was most practices as compare to laissez-faire and autocratic managerial style and the mean score 2.309 of autocratic managerial style shows that this style was least practices as compare to democratic and laissez-faire managerial style.

Table2

Comparison in Means of Managerial styles of head teachers and PCOT \& OCOT

\begin{tabular}{llll}
\hline Variables & Mean & Variables & Mean \\
I.V & score & D.V & Score \\
\hline AMS & 2.30 & Professional commitment & 4.28 \\
DMS & 3.90 & Organizational commitment & 4.18 \\
LMS & 3.12 & & \\
\hline
\end{tabular}

Table 2 explains the managerial style of head teachers and professional commitment level of Teachers highest mean score 3.90of democratic managerial style confirm that dominant managerial style is democratic and the mean score 4.28 of Professional commitment and mean score 4.18 of OCOT show the high level of OCOT and PCOT.

Table 3

Gender wise comparison about the dominant managerial style by independent $\mathrm{t}$-test

\begin{tabular}{lllllll}
\hline $\begin{array}{l}\text { Management } \\
\text { Style }\end{array}$ & Gender & $\mathrm{N}$ & Mean Score & $d f$ & $t$-value & $p$-value \\
\hline DMS & Male & 274 & 3.79 & 538 & -4.402 & .000 \\
& Female & 266 & 4.02 & & & \\
\hline *Significance level p value at $0.05 \alpha=(p<0.05)$ & & & & &
\end{tabular}

Table 3 depicts that gender wise comparison about dominant management style of head teachers. Gender wise Mean scores of democratic management style of head teachers (Male $=3.79$, Female $=$ 4.02) $\mathrm{t}$ value $(\mathrm{t}=-4.402)$ and the $p$ value $(p=0.000, p<0.005)$ shows that there is slightly difference in perception of male and female teachers about their head teachers' dominant managerial style. 
Table 4

Gender wise comparison about the OCOT \& PCOT by using independent sample t- test

\begin{tabular}{lllllll}
\hline Variables & Gender & $\mathrm{N}$ & Mean & $d f$ & $t$-value & $p$-value \\
\hline \multirow{2}{*}{ PCOT } & Male & 274 & 4.20 & 538 & -4.619 & .000 \\
\multirow{2}{*}{ OCOT } & Female & 266 & 4.37 & & & \\
& Male & 274 & 4.12 & 538 & -3.231 & .001 \\
& Female & 266 & 4.25 & & & \\
\hline *Significance level $p$ value at $0.05 \alpha=(p<0.05)$ & & & &
\end{tabular}

Table 4 depicts the major division of scores that gender wise mean score of PCOT and OCOT are significant different. The $\mathrm{p}$ value and $\mathrm{t}$ value of PCOT $(p=.000<0.05, \mathrm{t}=-4.619)$ and OCOT $(p=.001<0.05, \mathrm{t}=-$ 3.231) reject the null hypothesis that there is no significant difference between the perceptions of male and female teachers about their OCOT and PCOT. It is concluded that male and female teachers have significant difference in their opinion about their professional and organizational Commitment.

Table 5

Relationship of HTMS with OCOT and PCOT by Pearson correlation $(\mathrm{N}=540)$

\begin{tabular}{lllll}
\hline Variables(IV) & PCOT(DV) & Sig. (2-tailed) & OCOT(DV) & Sig. (2-tailed) \\
\hline AMS & $-0.113^{\star *}$ & 0.009 & $-0.133^{\star *}$ & 0.002 \\
DMS & $0.390^{* *}$ & 0.000 & $0.383^{\star *}$ & 0.000 \\
LMS & 0.043 & 0.43 & 0.063 & 0.141 \\
**. Correlation is significant at the 0.01 level (2-tailed). & &
\end{tabular}

Table 5 explains the relationship of HTMS with OCOT and PCOT and, calculated value show that AMS is negatively correlate with OCOT and PCOT with LMS style is slightly correlated whereas DMS is significant positively correlate with teachers' professional and organizational commitment. 
Table 6

Model Summary or Regression Analysis

\begin{tabular}{lllll}
\hline $\begin{array}{l}\text { Managerial } \\
\text { styles }\end{array}$ & \multicolumn{2}{l}{ professional commitment } & \multicolumn{2}{l}{ Organizational commitment } \\
\hline Predictors & $\mathrm{R}$ & $\mathrm{R}$ Square & $\mathrm{R}$ & $\mathrm{R}$ Square \\
AMS & $0.013^{\mathrm{a}}$ & 0.013 & 0.133 & 0.018 \\
$\mathrm{DMS}$ & $0.390^{\mathrm{a}}$ & 0.152 & 0.383 & 0.147 \\
LMS & $0.043^{\mathrm{a}}$ & 0.002 & 0.063 & 0.004 \\
\hline a. Predictors: (Constant), Laissez-faire, Democratic, Autocratic
\end{tabular}

Table 6 explains Regression analysis of DMS, PCOT and OCOT show, (PCOT) $\mathrm{R}^{2}=0.152$ \& $(\mathrm{OCOT}) \mathrm{R}^{2}=0.147$. This means that $15.2 \%$ of variance in PCOT of respondents is due to DMS and $14.7 \%$ variance in OCOT of respondents is also due to DMS. A low value of $\mathrm{R}$ means that there is a weak or no linear correlation. This may also mean that there is a random or nonlinear relationship between the two variables. Therefore it is concluded that DMS has significant relationship with PCOT and OCOT whereas the AMS and LMS have weak or no correlation.

Table 7

Regression coefficients $(\beta)$

\begin{tabular}{llllll}
\hline Predictor & \multicolumn{2}{l}{ Un standardized Coefficients } & $\begin{array}{l}\text { Standardized } \\
\text { Coefficients }\end{array}$ & $t$-value & $p$-value \\
\hline & $\mathrm{B}$ & Std. Error & Beta & & \\
\hline Managerial Style & PCOT & & & & \\
\hline AMS & -0.070 & 0.27 & -0.113 & -2.631 & 0.009 \\
DMS & 0.277 & 0.28 & 0.390 & 9.821 & 0.000 \\
LMS & 0.039 & 0.039 & 0.043 & 1.007 & 0.314 \\
\hline \multicolumn{7}{l}{} & & & & \\
\hline OMS & -0.089 & 0.069 & -0.113 & -3.112 & 0.002 \\
DMS & 0.294 & 0.031 & 0.383 & 9.627 & 0.000 \\
LMS & 0.062 & 0.042 & 0.063 & 1.473 & 0.141 \\
\hline a- Dependent Variable: professional (PCOT) and organizational commitment (PCOT) &
\end{tabular}

b- Predictors: Managerial styles (AMS, DMS\&LFS)

Table 7 shows the results of regression coefficients $(\beta)$ of the two independent variables. Regression coefficient of AMS is low and negative (PCOT \& OCOT) $=(\beta=-0.113 \& \beta=-0.113)$ which indicates that one unit change of AMS will cause -0.113 unit changes in PCOT \& 
OCOT in a negative direction. Similarly regression coefficient of DMS is moderate $($ PCOT \& OCOT $)=(\beta=0.390 \& \beta=0.383)$ and significant. This implies that one unit change in DMS will cause 0.390 \& 0.383 unit change in PCOT \& OCOT. Regression coefficient for LMS is very low $($ PCOT \& OCOT $)=(\beta=0.043 \& \beta=0.063)$ and not significant, meaning that the impact of this construct is minimal. This may also mean that democratic managerial style of head teachers has significant positive effect on professional and organizational commitment of teachers.

\section{Results}

Findings of the study showed that among the managerial styles of head teachers, democratic managerial style $($ Mean= 3.90$)$ was the dominant and the most practiced as compared to laissez-faire (Mean= 3.12) and autocratic managerial style whereas the autocratic managerial $($ Mean= 2.30) style was least practiced as perceived by teachers. The professional $($ Mean $=4.28)$ and organizational commitment (Mean= 4.18) levels of the teachers were high and significant correlated $(M e a n=4.18)$ with head teachers' managerial style, and democratic managerial style was found positive correlated with teachers' professional and organizational commitment (PCOT $r=0.390 \&$ OCOT $r=0.380$ ). Regression analysis showed that the head teachers' democratic managerial style had positive effect on teachers' professional and organizational commitment while autocratic style was found correlated negatively.

\section{Discussion}

The parameters define in the questionnaires for the indication of managerial styles of head teachers are helpful in determining the dominant managerial style of head teachers thus democratic managerial style is determine as a dominant managerial style of the head teachers whereas the laissez-faire managerial style is found to be practiced and up to some extent the autocratic managerial Style of the head teachers is also practiced.

Most of the teachers are committed with their profession and organization due to their head teachers behavior and their head teachers are in practice to encourage and motivate them and provide valuable guidance that is infusing commitment in them. It was concluded that teachers have same opinion about the managerial style of head teachers and also have same opinions about professional and organizational commitment. These findings are in accordance with our present 
circumstances where we cannot find any concept of head teachers' leadership and behavior but this concept is just related with management. That's why we can observe that our educational administrators and policy makers do not give any deliberation, trainings, and awareness to leadership as well as managerial 'traits of the head teachers. Therefore, it may be the cause why they are not aware about managerial' role and its effectiveness. This situation brings forward the reality. In consistence with the findings of the studies carried out by Asgari and Mahjoob (2013), and also in line with results of Machumu and Kaitila (2014).

The results shows that teachers are highly committed due to managerial style of theirs head teachers along with others factors like intrinsic motivation, positive effective supervision as well as other leadership styles may influence in teachers' commitment these findings in line with the results of Cemalog/lu, Sezgin and Kılınç (2012), Javaid and Mirza (2013), Ling and Ibrahim (2013) and Munaf (2011).

\section{Conclusions and Recommendations}

The research result revealed that among the managerial styles of head teachers, DMS is the most practiced as compared to laissez-faire and autocratic managerial. The professional organizational and commitment (Mean score 4.18) levels of the teachers are high and significant correlated (Mean score 4.18) with head teachers' managerial style, and DMS was found positive correlated with teachers' professional and organizational commitment. Therefore, following recommendations are made on the basis of findings and conclusions:

1. Head teachers' managerial style is directly linked with commitment so the head teachers may adopt democratic managerial style to enhance the professional and organizational commitment of teachers.

2. Directorate of Staff Development Punjab may arrange special trainings for the head teachers to adapt democratic managerial style to enhance the commitment level of teachers.

3. Head teachers may develop passion of duty and commitment in teachers by making educational and organizational plan with the collaboration of teachers and assigning duties according to their abilities, interests and willingness.

4. The effect of other variables on teachers commitment like national policies, behavior, managerial style and supervision, cooperation of community and parents, work environment, academic qualification, professional qualification and experience of teachers, may be examine in further studies. 


\section{References}

Academy of Educational Planning and Management. (2009). Pakistan education statistics 2007-08. Islamabad: Ministry of Education.

Ahmad, I. (2004). Islam, Democracy and Citizenship Education: An Examination of the Social Studies Curriculum in Pakistan.Current Issues in Comparative Education, 7(1), 39-49.

Allen, N. J., \& Meyer, J. P. (1993). Organizational commitment: evidence of career stage effects? Journal of Business Research, 26(1), 49-61.

Asgari, M. H., \& Mahjoob, S. H. (2013). Relationship between participatory management and teacher's organizational commitment. International Research Journal of Applied and Basic Sciences,4 (2), 471-476.

Bagraim, J. J. (2003). The dimensionality of professional commitment. South African Journal of Industrial Psychology, 29(2), 6-9.

Burcak, C. G. (2013). Examining organizational commitment of private school teachers. Journal of Educational \& Instructional Studies in the World, 3(2), 22-28.

Brown, M., \& Owusu, A. A. (2014). Influence of Head teachers' Management Styles on Teacher Motivation in Selected Senior High Schools in the Sunyani Municipality of Ghana. International Journal of Learning, Teaching and Educational Research, 4(1).

Bush, T. (1989). Managing education: theory and practice: Islamabad: Allama Iqbal Open University.

Bush, T. (1995). Theories of educational management. (2nd ed.). London: Paul Chapman.

Bush, T. (1999). Crisis or crossroads? The discipline of educational management in the late 1990s. Educational Management Administration \& Leadership, 27(3), 239-252. 
Bush, T. (2003). Theories of educational leadership and management. International Journal of Educational Management. 18(3), 205.

Bush, T. (2006).The National College for School Leadership: Phi Delta Kappan: A sucessful English innovation, 87(7), 508-511.

Cemaloglu, N., Sezgin, F., \& K1lınc, A. (2012). Examining the relationships between school principals' transformational and transactional leadership styles and teachers' organizational commitment. The Online Journal of New Horizons In Education, 2(2), 53-64.

Certo, S. C. (2003). Modern management: adding digital focus.Prentice Hall.(Vol. 1).

Chan, W. Y., Lau, S., Nie, Y., Lim, S., \& Hogan, D. (2008). Organizational and personal predictors of teacher commitment: The mediating role of teacher efficacy and identification with school. American Educational Research Journal, 45(3), 597-630.

Day, C. (2000). Beyond Transformational Leadership. Educational leadership, 57(7), 56-59.

Elliott, B., \& Crosswell, L. (2002). Teacher commitment and engagement: The dimensions of ideology and practice associated with teacher commitment and engagement within an Australian perspective. Paper presented at the Australian Educational Research Association Conference, Brisbane.

Fullan, M. (2002).The role of leadership in the promotion of knowledge management in schools. Teachers and Teaching: theory and practice, 8(3), 409-419

Gehlawat, M. (2013). Organizational commitment in relation to job satisfaction and work motivation of secondary school teachers working in different types of schools. India:Maharshi Dayanand, Department of Education. URl: http://hdl.handle.net/10603/8343.

Gerald, S. (2011). Rewards and job commitment of primary school teachers in Mityana District.Mityana: Doctoral dissertation, Makerere University. 
Grosso, F. A. (2008). Motivating faculty through transformational leadership: A study of the relationship between presidential leadership behaviors and faculty behaviors: America: ProQuest.

Hamidifar, F. (2010). A Study of the Relationship between Leadership Styles and Employee Job Satisfaction at IAU in Tehran, Iran. AuGsb e Journal, 3(1).

Hanlon, M. D. (1983). Age and the Commitment to Work. Paper presented atthe Annual Scientific Meeting of the Gerontological Society. (ERIC Document Reproduction Service No.ED243003)

Javaid, M. F., \& Mirza, M. U. (2013). Leadership Style Enhances The Employee Organizational Commitment: A Case Study of Educational Institutions in Lahore. Paper presented at the International Journals and Conference of Management, Statistics and Social Sciences. URL: http://localhost/icjmsss. Accessed on.18,September, 2014.

Kraus, R. G., \& Curtis, J. E. (1986). Creative management. Canada: Times Mirror/Mosby College Publishers, Toronto, ON, Canada.

Lambertz, L. (2002). Beyond Instructional Leadership, Educational Leadership. 59(8), 37-40.

Leithwood, K., Jantzi, D., \& Steinbach, R. (1999). Changing leadership for changing times.UK: McGraw-Hill Education.

Lewin, K., Lippitt, R., \& White, R. K. (1939). Patterns of aggressive behavior in experimentally created "social climates". The Journal of Social Psychology, 10(2), 269-299.

Ling, S. L. M., \& Ibrahim, M. S. (2013). Transformational Leadership and Teacher Commitment in Secondary Schools of Sarawak. International Journal of Independent Research and Studies, 2(2), 5165.

Machumu, H. J., \& Kaitila, M. M. (2014). Influence of leadership styles on teachers job satisfaction: A case of selected primary schools in 
Songea and Morogoro districts, Tanzania. International Journal of Educational Administration and Policy Studies, 6(4), 56-61.

Maheshwari, S., Bhat, R., \& Dhiman, A. (2007). Implications of Human Resource Practices and Other Structural Factors on Commitment of Public Medical Professionals in India.IIMA Institutional Repository. URI: http://hdl.handle.net/123456789/141

Marmaya, N., Hitam, M., Torsiman, N. M., \& Balakrishnan, B. (2011). Employees' perceptions of Malaysian managers' leadership styles and organizational commitment. African Journal of Business Management, 5(5), 1584-1588.

Massie, J. L. (1992). Essentials of Management. New Delhi: PrenticeHall of India Pvt. Ltd., 50-54(131-132), 1-7.

Mowday, R. T., Steers, R. M., \& Porter, L. W. (1979). The measurement of organizational commitment. Journal of Vocational Behavior, 14(2), 224-247.

Munaf, S. (2011). Relationship of transformational, transactional and passive/avoidant management style with achievement motivation of teaching faculties of selected educational institutions of Pakistan. Paper presented at the International Conference on E-business, Management and Economics.

Nazari, K., \& Emami, M. (2012). Analysis of relation between organizational commitment and professional commitment. Elixir International Journal, 51(2012), 10661-10664.

Northouse, P. G. (2010). Leadership: Theory and Practice.(5th ed.).California: SAGE Publications.

Ribbins, P. (1999). On Redefining Educational Management and Leadership. Editorial. Educational Management \& Administration, 27(3), 227-238.

Robbins, S. P., Decenzo, D. A. \& Coulter, M. (2010). Fundamentals of Management: Essential Concepts and Applications. (7th ed.). New Jersey: Prentice Hall, New Jersey. 
Swanepoel, B., Erasmus, B., Van Wyk, M., \& Schenk, H. (2000). South African human resource management: Theory and practice. Kelwyn: Juta \& Co: Ltd.

Thomas, M. (1999). Administrator's Perception of Pre and Post Service Barriers to Effectiveness. Ph.D. Thesis. SGS. State University, Youngstown., 202-203

Walumbwa, F. O., Lawler, J. J., Avolio, B. J., Wang, P., \& Shi, K. (2005). Transformational leadership and work-related attitudes: The moderating effects of collective and self-efficacy across cultures. Journal of Leadership \& Organizational Studies, 11(3), 2-16.

Ware, H., \& Kitsantas, A. (2007). Teacher and collective efficacy beliefs as predictors of professional commitment. The Journal of Educational Research, 100(5), 303-310.

Yukl, G. (1994). Leadership in organizations. New York:Prentice-Hall lnc.

Received on: January 17, 2016

Revised on: May 07, 2016

Accepted on: June 05, 2016 